\title{
There is No such Thing as a Free Open Sky: Financial Markets and the Struggle over European Competences in International Air Transport*
}

\author{
CHRISTIAN RAUH ${ }^{1}$ and GERALD SCHNEIDER ${ }^{2}$ \\ ${ }^{1}$ Social Science Research Center Berlin (WZB). ${ }^{2}$ University of Konstanz
}

\begin{abstract}
Aviation is a prime example of a policy area where the clash over supranational regulatory responsibilities had pronounced economic repercussions. In this article, we examine the economic effects of the European Commission's struggle to obtain competences in international air transport. Stock market reactions to key events in the political conflict between 1995 and 2004 unravel whether investor beliefs about the distribution of power in the EU follow the basic conjectures of neofunctionalism, intergovernmentalism or institutionalism. The event studies show that particularly judicial proceedings and the involvement of the ECJ send credible integration signals to financial markets. This supports the hypothesis that investors consider the subtleties of the EU's decision-making apparatus carefully and only react to developments that definitively alter the political regime and thus also the market situation. These findings are in line with an institutionalist interpretation of a reform that has radically changed the international aviation regime.
\end{abstract}

\section{Introduction}

Chicago-Brussels is one of the aviation routes covered by the first 'Open Skies' agreement between the European Union (EU) and the United States of America. This agreement allows all European and American carriers to freely enter the markets between both territories. Chicago-Brussels, at the same time, metaphorically describes the journey that the international air transport regime has made since its 'take-off' after World War II. The 1949 Chicago Conference failed to build a multilateral framework, thereby creating a paradoxical industry: while crossing borders touches the very core of aviation, the regulatory regime was strictly built on national sovereignty. Yet, after having established a common air transport market in the mid-1990s, the European Commission started to fight for own competences in external aviation and the abolition of nationality barriers. Since its demands met the resistance of European Member States, a political conflict unfolded which the EU only managed to settle in 2004.

Political scientists have frequently focused on air transport to study the patterns and conditions by which the European Commission asserts its regulatory ambitions against

\footnotetext{
* A previous version of the article has been presented at the 'International Aviation: Political, Legal, and Economic Perspectives' workshop, Institut Barcelona d'Estudis Internacionals (IBEI), 15 October 2010. We would like to thank especially Andreas Dür, Cornelia Woll, Hussein Kassim, Alan P. Dobson and two anonymous reviewers for valuable comments. Data and statistical routines are available at the authors' websites.
} 
national resistance (for example, Delreux, 2011; Dobson, 2010; Kassim and Stevens, 2010; Woll, 2006; O'Reilly and Stone-Sweet, 1998). We complement this literature by scrutinizing how financial markets perceive political struggles over supranational liberalization in Europe. We ask which events of the decade-long conflict on nationality barriers in aviation credibly signalled regime change from the perspective of market participants. Our aim, in other words, is to identify the actors that are able to influence markets and in this way to unravel the theory that financial investors have about the distribution of power at the supranational level. Integration theory provides conflicting predictions in this regard. Intergovernmentalists expect that the decisions made by the Council are the most relevant market signals. Neofunctionalists, conversely, anticipate that the early agenda-setting efforts of the European Commission heralded a regime change and thus led market participants to adapt their expectations. From the perspective of rational institutionalism, finally, investors should follow political conflicts in a more detailed manner to identify events that alter the balance of power. The coalition of the European Commission and the European Court of Justice (ECJ) can, according to this theoretical vantage point, credibly signal a changing status quo despite national resistance to Europeanization.

To test these conflicting expectations on the economic relevance of different EU institutions, we rely on an event study design. In line with financial econometrics we assume that share price fluctuations provide an unbiased measure of the extent to which investors expect distributional effects from political signals. To see whether and how they adapted their expectations on the future profitability of European and American airline companies in response to the Commission's inroad into the extra-European aviation market, we analyze the so-called 'abnormal returns' of airline shares as a response to 27 crucial events that ultimately led to the regime change from Chicago to Brussels. The findings suggest that investors' assessments of political conflicts over European integration are in line with the interpretation of rational institutionalism. While the initial agenda-setting efforts of the Commission and Council resistance hardly affected investor expectations, the picture changed when the Commission started to threaten the Member States judicially. The initiation and conclusion of infringement procedures involving the ECJ conveyed meaningful information. Cumulated returns additionally suggest that it is mainly investors of American and smaller European airlines that benefited from the final Commission success while a portfolio of the largest EU carriers remained largely unaffected by the power struggle between Member States and the supranational institutions. We thus conclude that financial market participants closely track the subtleties of long-term EU politics, that they are aware of the immense relevance of judicial strategies in European integration, and that their stock market reactions provide a valuable data source for assessing the credibility of political moves at the supranational level.

\section{Financial Markets and the Credibility of Political Signals on European Integration}

It is a truism that economics and the politics of European integration are strongly interrelated. Nevertheless, the political science literature tends to focus on one side of this relationship only. While the influence of economic preferences on politics drives most 
modern integration theories, the effects of supranational political events on the supposedly affected markets rarely meet scholarly attention. But if political events are driven by economic considerations, then economic responses should also reveal information about political events.

Scholars frequently disregard such information, however, because the major economic repercussions of political decisions take a long time to materialize. No airline adapts its route network, merges with a competitor or goes bankrupt immediately after a politically credible decision. Such responses may happen years later and many confounding factors limit our ability to attribute economic effects to particular political actions. However, short-term investor assessments provide a means to proxy the long-term consequences of very specific political events and, in this indirect way, allow the social scientists to assess which theory of political decision-making financial market participants predominantly hold. This idea rests on two common assumptions made to explain financial market behaviour. First, we need to understand financial assets as claims on real assets and the future stream of income attached to them (Howells and Bain, 2001, p. 213). The current value of airline shares, for example, should mirror the aggregate investor expectations on the future profitability of this airline. Second, by and large financial markets are assumed to be informationally efficient so that a share price reflects all publicly available information (Howells and Bain, 2001, p. 541; Fama et al., 1969).

Investors are consequently assumed to act rationally in a Bayesian sense: new information may update their beliefs about the future asset price. If the posterior belief is lower than the prior one, an individual investor will wish to sell the respective asset; if it is higher he or she will want to buy it. In the aggregate, the asset price will thus adapt immediately if relevant information hits the market. These crowd reactions have two attractive analytical features: first, they allow us to tap into contemporaneous assessments as investors can only act on the basis of the information available at the time; and second, they provide politically unbiased assessments as investors are driven by economic self-interests.

Along these assumptions, economists have evaluated the distributional effects of a myriad of regulatory changes (for example, Binder, 1985a; Lamdin, 2001). Political scientists have more recently started to exploit financial market responses to study a broad variety of political phenomena. Investor reactions were, for instance, used to assess the economic consequences of anticipated partisan government (Füss and Bechtel, 2008) or violent political conflicts (Schneider and Tröger, 2006). Yet, for questions of EU integration, this approach has hardly been utilized so far. An exception is the study of Bechtel and Schneider (2010), which reveals that the defence industry gains significantly from political moves towards a common European defence policy. Highlighting that investor reactions vary over European Council meetings, Bechtel and Schneider demonstrate that markets discriminate between intergovernmental summits that produce 'hot air' only and credible political signals for further European integration.

This logic can be applied to the day-to-day political struggles in Brussels as well. In fact, asking which events send credible signals to markets directly relates back to core questions of integration theory. Who do markets think is in charge over the future course of integration? Which political actions actually change investor expectations on the regulatory context of their investments? Integration theory holds vastly different answers. Liberal intergovernmentalists, for example, argue that integration is a function of domestic interests. We can only expect further integration if there is some bargaining space at the 
intergovernmental level or if the more ambitious Member States are able to pay off the more reluctant ones (Moravcsik, 1993). In this view, credible political signals come solely from a changed aggregate position of Member States. Investors should thus react mainly to Council meetings as only they reveal information on the pivotal political actors $(\mathrm{Hl})$.

Neofunctionalists, by contrast, would opt for a rather different investment strategy. In their view, supranational institutions and particularly the Commission control powerful agenda-setting strategies to overcome Member State resistance. Integration is thus set on track once the Commission clearly articulates the will to move a particular regulatory competence to the supranational domain (O'Reilly and Stone-Sweet, 1998). Especially in sectors where some European competences already exist and spillovers are likely, early Commission commitments should be the most credible signals for investors (H2).

Rational institutionalists provide a more nuanced view on conflicts between the Commission and the Council. They accept that Member States constrain the Commission in principle, but argue that that the interplay of institutional set-up and preference constellations can create supranational autonomy (Pollack, 1997). Essentially, these approaches state that supranational actors may enact any policy as long as it is not vulnerable to re-legislation by the Member States. They often focus on bureaucratic drift in areas where certain legislative competences have been delegated already (Franchino, 2007). Yet, the underlying logic also operates at the more fundamental level of the European treaties and in areas where supranational responsibility is still in question. If the Commission can credibly make the case that specific national competences violate the hard-to-renegotiate treaty provisions, Member State resistance can be overcome. Thus, institutionalist scholars emphasize the powers of the ECJ in interpreting primary law (for example, Tsebelis and Garrett, 2001; Scharpf, 2010). Susanne Schmidt (2000) has theorized how the Commission can exploit the judicial powers that the ECJ has created through the doctrines of direct effect and supremacy of supranational law. If the Commission is able to win the Court as an ally in treaty infringement procedures against individual reluctant Member States, it effectively alters the fallback option and thus the Member State's preference for a supranational re-regulation of the regulatory competence in question (see also Woll, 2006). This theory requires investors to follow the details of policy-making in Brussels more closely, but the empirical implication is clear: if investors belief in this distribution of power, particularly judicial actions and an alliance of the Commission and the ECJ send credible signals to financial markets $(H 3)$. As we will see, the conflict on supranational competences in external aviation has all the necessary ingredients to analyze these different expectations on the investors' assessments of political power in Europe.

\section{From Chicago to Brussels: The Conflict on Nationality Restrictions}

\section{The Chicago Regime and Its Transformation in Europe}

The international aviation regime dates back to the 1944 Chicago International Civil Aviation Conference (Doganis, 2002, p. 30), which set different levels of market access that governments reciprocally exchange on a route-by-route basis (Havel, 1997, pp. 35-40). Based on these 'Freedoms of Air', bilateral agreements became the prime source of international air transport regulation. Importantly, third states have to be excluded from such bilaterals along the nationality clause that carves the protectionist nature of the Chicago regime into stone: 
Each [c]ontracting [s]tate reserves the right to withhold or revoke a certificate or permit to an air transport enterprise of another [s]tate in any case where it is not satisfied that substantial ownership and effective control are vested in nationals of a contracting [s]tate. (Quoted in Havel, 1997, p. 52)

The bilateral provisions created a multitude of duopolies and oligopolies and accounted for the perseverance of national flag-carriers and close government-airline relationships all over the world. Nationality restrictions severely constrain airlines in building an attractive route network and imply that majority changes in the ownership structure entail the loss of indispensable traffic rights (Chang and Williams, 2001). For certain companies, however, this regime was a boon rather than a handicap as it forestalled the entry of more powerful competitors.

In the late 1970s the United States highlighted this protectionist potential when it used nationality restrictions to enhance market access for its airline industry, which was aching to exploit the increasingly efficient and large home market that domestic deregulation had created (Doganis, 2001, pp. 23-5). Using this domestic market as bait and starting with the Netherlands in 1978, the United States successfully offered a limited number of additional gateways to small states whose flag-carriers were disproportionately dependent on international connections. Belgium, Germany and other states followed suit as they feared a diversion of traffic to Amsterdam's Schiphol airport and the American 'divide-and-rule' strategy on the basis of the nationality restrictions worked out (Staniland, 1996, pp. 4-5).

Based on these successes, American airlines pushed their government into what was termed 'open skies' bilaterals. The Netherlands were again the first willing partner in 1992. Other European governments did not give in so easily this time, but the American administration threatened to withhold approval of alliances unless their governments signed a revised bilateral (Doganis, 2001, p. 33). This threat was successful because nationality clauses effectively forestalled airline mergers which left alliances as the only way to benefit from larger networks, feeder traffic and code-sharing agreements (Chang and Williams, 2001). Nine European governments immediately started to renegotiate, and by 1998 Germany, France and Italy had signed new bilaterals (Doganis, 2001, p. 35). Only the United Kingdom negotiations proved thorny since the British government refused giving away access to Heathrow - the home base of British Airways and a hub that profited from its geographic advantage and linked five continents. American competition authorities repeatedly denied the alliance of British Airways and American Airlines in turn, while other European carriers could conclude such agreements. With the help of nationality clauses, and despite the liberal rhetoric surrounding them, the American 'open skies' agreements thus reproduced the protectionist nature of the Chicago regime.

Nationality restrictions were more profoundly challenged in Europe. In particular, the United Kingdom and the Netherlands mimicked American 'tailor-made' liberalization by removing restrictions for their European feeder traffic so as to exploit it in the North Atlantic market where it was protected against competitors (Morrell, 1998, pp. 44-5). Both countries also supported the multilateral approach of the European Community, which created a truly common air transport market by essentially requiring governments to grant operating licences if the airline is substantially owned and effectively controlled by nationals of any EC Member State (Kassim, 1996, pp. 115-17). This concept of a 
'Community carrier' turned the Chicago regime upside down. For the first time in international aviation, market entry was no longer dependent on nationality. As a consequence, six new airlines emerged within three years, while frequencies, capacity and routes increased steadily (Kassim, 1996, p. 125; Commission, 2007). Yet in the economically much more relevant long-haul markets beyond Europe, nationality clauses remained untouched initially (Staniland, 1996).

\section{Brussels' International Liberalization Effort}

The ambition of the European Commission was, however, not confined to the internal aviation market (Woll, 2006). Brussels' international campaign gained momentum when the Santer Commission took the helm in 1995. With the formal backing of the College of Commissioners, the new Commissioner for Transport, Neil Kinnock, urged the Member States to cede any bilateral talks with the United States and claimed that nationality restrictions might contradict EU law. As the governments ignored this request, the aviation regime on extra-European routes entered the nine-year period of political uncertainty that we are analyzing here.

The Council granted a Commission mandate against British opposition in 1996, but limited it to soft rights such as ground-handling or maintenance (Doganis, 2001, p. 54). Kinnock, however, repeatedly targeted the hard traffic rights, arguing that bilateral agreements contradicted the division of labour in EU trade policy-making, and that they discriminated on the grounds of nationality and were thus not in line with the Community carrier principle (Woll, 2006, pp. 61-2; Staniland, 1999, pp. 17-18). These arguments implied the abandonment of any remaining governmental sovereignty over the economic fate of a nation's flag-carrier. Accordingly, Member States did not give in as made clear by the ongoing German, French and Italian negotiations with the United States.

The Commission increased the pressure and took eight Member States to the ECJ, arguing that nationality restrictions infringe the European treaties (Sorensen et al., 2003, pp. 7-8). The Dutch government deliberately joined the case in support of the other Member States, and France, Italy and the United Kingdom kept negotiating with the United States. Despite Member State resistance, however, the ECJ finally sided with the Commission. The 'open-skies' rulings in November 2002 promoted a shared competence in external aviation and, more importantly, rendered the nationality clauses incompatible with EU law (Woll, 2006).

The Commission used this as a stepping stone and pushed further for the renouncement of bilateral agreements. The Council ultimately surrendered by agreeing a re-regulation of extra-EU air traffic that prescribed the inclusion of a Community designation clause in agreements with third states. It ultimately became law in April 2004, and European flag-carriers as well as foreign airlines took off into future markets that were open to an unprecedented degree of competition.

In sum, the conflict on external aviation relations has all the necessary ingredients to test the predictions about the credibility of political signals on European integration. On the one hand, the disputed regime change was clearly relevant for the economic fate of European and American airlines so that investors should be automatically interested in planned and realized policy developments. On the other hand, the outcome of this political 
struggle, which involved intergovernmental decisions, supranational agenda-setting as well as judicial actions, was highly uncertain and it is not obvious which political events between the initiation of the Commission strategy in 1995 and the re-regulation in 2004 conveyed credible political signals for a changing regime.

\section{Research Design}

\section{Political Event Data}

To cover all publicly visible events of the conflict in the period 1995-2004 we systematically analyzed the contents of the Financial Times $(F T)$. Since the FT is the largest daily newspaper with a Europe-wide outreach and maintains an American subsidiary, we are confident of having identified all potentially relevant actions this way. A set of descriptive keywords tracked down 384 articles that were coded along systematic instructions (see the web appendix). ${ }^{1}$ We tested the reliability with a subsample of 160 articles; the inter-coder agreement amounted to 86.25 per cent. Note that we ignored commentaries without references to actual political events, repeated event reports as well as unilateral actions.

Table 1 lists the resulting 27 publicly visible events that sent political signals in the conflict on nationality restrictions in European air service agreements. The Commission initiated most events, followed by the Council and the ECJ. The event sample, which involves formal steps as well as negotiation tactics such as threats, captures the major political turning points neatly.

\section{Airline Sample and Financial Data}

To test the market relevance of these events, we focused on airlines that had an operating licence as a Community carrier and were considered to be a flag-carrier of a European Member State as indicated by the membership in the Association of European Airlines (AEA) (Staniland, 1996). This resulted in two airlines in the United Kingdom and we preferred BA over BMI as the latter only served two international destinations (AEA, 2004).

We further restricted the analysis to companies that were publicly listed throughout the entire nine years studied as identified by the airline websites and the Worldscope database. The web appendix presents the sample of European flag-carriers including Air France (AFR), Alitalia (AZA), Austrian Airlines (AUA), British Airways (BAW), Deutsche Lufthansa (DLH), Finnair (FIN), KLM of the Netherlands and Scandinavian Airlines (SAS) in more detail. We are confident that no significant selection bias is present. ${ }^{2}$ However, varying free float - that is, the proportion of all actually tradable shares - has to be noted. Indeed, governmental stakes in flag-carriers differ across companies and time. This may induce limits on the variability of share prices, but poses no major problem as our analyses focus on relative price changes only.

More importantly, the selected European airlines vary strongly in size and dependence on extra-EU traffic and may thus react differently to the political conflict (see the web

\footnotetext{
${ }^{1}$ The web appendix, replication data and the statistical scripts are available at: «http://www.polver.uni-konstanz.de/ en/gschneider/working-papers/replication-data/».

${ }^{2}$ A company's decision to issue shares may depend on its profitability so that more efficient companies are always over-represented in financial studies. Aer Lingus, Olympic Airways and Sabena were European flag-carriers not traded publicly, while Iberia did not go public until 2001.
} 
Table 1: Event Data

\begin{tabular}{|c|c|c|}
\hline $\begin{array}{l}\text { Event } \\
I D\end{array}$ & Date & Description \\
\hline \multicolumn{3}{|c|}{ Agenda-setting } \\
\hline 1 & 01.03 .1995 & College of Commissioners backs the aggressive strategy of Transport Commissioner Kinnock \\
\hline 2 & 14.03.1995 & $\begin{array}{l}\text { Council postpones decision on Commission mandate and demands report on economic } \\
\text { consequences of extant American agreements }\end{array}$ \\
\hline 3 & 19.04.1995 & $\begin{array}{l}\text { Commissioner Kinnock urges British government to desist from American negotiations; first } \\
\text { big Member State attacked }\end{array}$ \\
\hline 4 & 26.04.1995 & $\begin{array}{l}\text { College of Commissioners formally backs a proposal for a far-reaching aviation negotiating } \\
\text { mandate }\end{array}$ \\
\hline 5 & 25.05.1995 & $\begin{array}{l}\text { Commission initiates legal investigations against six Member States having signed } \\
\text { nationality-based aviation deals with the United States }\end{array}$ \\
\hline 6 & 02.06 .1995 & $\begin{array}{l}\text { Transport Commissioner Kinnock repeats his position in front of the Air Transport Users } \\
\text { Council in London }\end{array}$ \\
\hline 7 & 20.06.1995 & Transport Council basically endorses Commission approach and demands an impact assessment \\
\hline 8 & 06.12 .1995 & $\begin{array}{l}\text { Commission publishes report on economic consequences of bilateral open skies deals } \\
\text { bolstering its political demands }\end{array}$ \\
\hline 9 & 17.06.1996 & $\begin{array}{l}\text { Transport Council agrees on a limited Commission mandate for negotiations with the United } \\
\text { States }\end{array}$ \\
\hline 10 & 27.06.1996 & $\begin{array}{l}\text { Commissioner Kinnock admits that the new mandate will not yet unravel existing bilaterals, but } \\
\text { that the Commission means to go further }\end{array}$ \\
\hline 11 & 30.10 .1996 & Commission officials begin talks with the United States in Washington, DC \\
\hline 12 & 14.01.1997 & $\begin{array}{l}\text { Commission threatens the United Kingdom with further legal investigations against a planned } \\
\text { BAW-AA alliance that was a major American demand }\end{array}$ \\
\hline 13 & 11.12.1997 & $\begin{array}{l}\text { Commission pursues legal investigations further after failing to get a widened mandate from the } \\
\text { Council }\end{array}$ \\
\hline \multicolumn{3}{|c|}{ Judicial action } \\
\hline 14 & 11.03 .1998 & $\begin{array}{l}\text { Commission sends reasoned opinions to Member States with open skies deals and the United } \\
\text { Kingdom - formal initiation of judicial action }\end{array}$ \\
\hline 15 & 01.10 .1998 & $\begin{array}{l}\text { Commission announces to file official ECJ cases after having finally lost yet another attempt to } \\
\text { gather the full negotiation mandate }\end{array}$ \\
\hline 16 & 30.10 .1998 & Commission formally files the open skies suit against eight Member States \\
\hline 17 & 06.02 .1999 & Commission formally files a case against the renewed Dutch open skies deal \\
\hline 18 & 31.01 .2002 & $\begin{array}{l}\text { ECJ/Advocate-General recommendation: nationality restrictions illegal, Commission mandate } \\
\text { not necessarily needed }\end{array}$ \\
\hline 19 & 26.02 .2002 & $\begin{array}{l}\text { Commission proposes legislation that would give it powers to renegotiate nationality } \\
\text { restrictions in Member States' bilaterals }\end{array}$ \\
\hline 20 & 28.05 .2002 & $\begin{array}{l}\text { Council/Coreper rules out the last stumbling blocks for an open skies mandate of the } \\
\text { Commission }\end{array}$ \\
\hline 21 & 17.10 .2002 & $\begin{array}{l}\text { Transport Commissioner warns the United Kingdom about continuing American talks and } \\
\text { suggests that the ECJ will render them illegal }\end{array}$ \\
\hline 22 & 05.11 .2002 & $\begin{array}{l}\text { ECJ announces its verdict in the open skies cases: nationality restrictions are incompatible with } \\
\text { European law }\end{array}$ \\
\hline \multicolumn{3}{|c|}{ Re-regulation } \\
\hline 23 & 29.01 .2003 & Commission warns that unilaterally redrafting the American open skies agreements is illegal \\
\hline 24 & 05.06 .2003 & $\begin{array}{l}\text { Transport Council grants the Commission mandate and agrees on a formal re-regulation of air } \\
\text { service agreements }\end{array}$ \\
\hline 25 & 30.09 .2003 & $\begin{array}{l}\text { Commission starts global campaign to convince foreign governments of the Community Carrier } \\
\text { principle }\end{array}$ \\
\hline 26 & 09.03.2004 & $\begin{array}{l}\text { Council demands more concessions from the United States and prolongs the Commission } \\
\text { mandate }\end{array}$ \\
\hline 27 & 14.04 .2004 & $\begin{array}{l}\text { Council approves EP amendments and the re-regulation of EU air service agreements becomes } \\
\text { law }\end{array}$ \\
\hline
\end{tabular}

Source: Content analysis of the Financial Times. 
appendix). Comparing the output of European carriers along their generated revenue passenger kilometres, Air France, BA and Lufthansa accounted for about 53 per cent of flag-carrier output in 1995 and 2000, and raised their share beyond 55 per cent in 2004. The fourth largest competitor, KLM, produced another 10 per cent of the overall market output. A similar pattern emerges for the geographical distribution of destinations. In 2000, more than 50 per cent of the destinations of Air France, BA and Lufthansa were located outside of Europe. While KLM followed closely with about 40 per cent, the extra-European share of the remaining European carriers was below 25 per cent. While one can thus broadly distinguish large and small European airlines, existing in-depth accounts of air transport regulation highlight that the competitive situation varied strongly over individual companies and also over time (see Dobson, 2010; Kassim and Stevens, 2010). We thus refrain from over-interpreting the directions of specific event effects. To assess its political credibility, we rather focus on whether a particular event had a statistically significant market impact at all.

American carriers were sampled if they served European destinations as confirmed by traffic statistics, and if their shares were tradable throughout the investigation period. The latter criterion was only fulfilled by two American airlines - American (AA) and Continental (COA). ${ }^{3}$ Specific generalizations to all American carriers thus have to be taken cum grano salis, but both included carriers were earlier profiteers of the American policy and were aching for more access to the European market.

We retrieved all financial time series from Thomson Datastream and merged them with the event data; weekend events were moved to the following trading day. The final data set consists of 2,554 trading days from 2 January 1995 to 14 May 2004.

\section{Analyzing Event Effects}

To test level effects in share prices on the basis of the assumptions outlined above, econometrics offers the event study approach (MacKinlay, 1997; Binder, 1998). It focuses returns on financial assets - that is, the relative price changes from one period to the next. In line with the literature, we use continuously compounded returns multiplied by 100 so that they present percentage points of continuous returns.

The fundamental idea of an event study is the distinction of estimation windows and event windows, which allows us to conduct a quasi-experiment. A model of 'normal' returns is derived during the estimation window and statistically meaningful deviations during the event window are then interpreted as 'abnormal' returns induced by the event of interest. We resort to a simple market model of normal returns that relates a share's return to a corresponding market portfolio (Chandra et al., 1990). By removing general fluctuations of the relevant financial market, the variance of abnormal returns is reduced, which in turn increases the ability to detect event effects. This approach is especially appropriate for the airline industry as passenger demand is sensitive to the broader economic developments in the country of origin (Doganis, 2002, pp. 196-7). To increase the signal-to-noise ratio further, we additionally include the price changes of jet-grade

\footnotetext{
${ }^{3}$ United Airlines and Northwest did not issue publicly tradable shares before 2004 and 2006, respectively. TWA faced delisting several times before it ceased operations in 2001. Delta Air Lines and US Airways were publicly traded at certain points during the investigation period, but we could not figure out the initial public offerings or potential interruptions. Furthermore, Delta was operating under bankruptcy protection from 2004 onwards and US Airways was taken over by American West and both were delisted.
} 
kerosene in Rotterdam and New York, respectively. As fuel accounts for approximately 12 per cent of airline cost (Doganis, 2002, p. 91), its price fluctuations explain variation in daily returns on airline shares (Michel and Shaked, 1984). Finally, we include a control variable to capture 9/11 and four consecutive trading days as the terrorist attacks had a disproportionately negative impact on airline shares (Carter and Simkins, 2004).

We estimated several variants of this basic model. For each airline, we fitted the regression with and without a constant, with either the home country's major blue-chip or its major all-share index as the relevant market portfolio, and with either lagged or contemporaneous market and kerosene regressors. The ordinary least squares (OLS) estimations rely on interrupted estimation windows that exclude five trading days prior and after the political events of interest, which leaves 1,954 daily observations. All of the 12 model combinations are plausible a priori, and our major consideration is solely the power to detect abnormal returns so that we chose the set-up that maximizes model fit for each airline.

The canonical event study set-up - focusing often on company specific events such as earnings announcements - simply subtracts the predicted normal return from the return during the event period, averages these abnormal returns over companies and then tests the null hypothesis of zero abnormal returns on the basis of the cross-sectional standard deviation.

For three reasons, the underlying assumption of identically and independently distributed residuals does not hold in the present context (Binder, 1985b, p. 371). First, the market model estimations show differing residual variances across airline companies. Second, the underlying economic fundamentals highlighted above lead us to expect that investors of the individual airlines respond differently to the political signals so that positive and negative reactions may be offset by averaging across firms (Lamdin, 2001, p. 173). And third, all scrutinized airlines are subject to unobserved industry-wide developments and they all experience the events of interest in the same calendar time leading to contemporaneously correlated prediction errors (Brown and Warner, 1980). Particularly the latter point has led scholars interested in the effects of regulatory announcements to parameterize the events directly in the market model along a set of dummy variables and then estimate the system of company equations jointly with generalized least squares (Binder, 1985b).

Besides enhanced efficiency of the event coefficients, the major advantage of this approach lies in testing industry-wide event effects. Having jointly estimated the system of company equations, post-estimation tests explicitly incorporate heteroskedasticity across equations and contemporaneous correlation of the disturbances (Binder, 1985b, p. 372). This allows us to evaluate the joint null hypothesis that - given the observed set of return effects in the individual return series - all abnormal returns during an event period are in fact zero.

Given contemporaneous correlation and different independent variables across the normal return estimations, we rely on the seemingly unrelated regressions (SURs) approach (Zellner, 1962) to estimate the system of equations. The main analysis relies on an event window that includes the event day and one consecutive trading day (0-E-1), which ensures that the relevant information has spread among investors. Robustness checks, reported in the web appendix, allow for leaked information by checking the 1-E-1 window, and account for possibly slower information processing by testing the 0-E-5 window. 


\section{Results}

Table 2 presents the results of the system of seemingly unrelated regressions for the 0-E-1 window around the 27 events. Although daily share price returns present stationary and highly volatile data, the overall model parameters build sufficient trust (lower panel). The proportion of explained variance is reasonable as compared to other financial market studies. As assumed earlier, the residuals of the individual estimations are correlated (see web appendix). This holds especially for the two American airlines but also the residuals of British Airways, Deutsche Lufthansa, KLM and partly Air France seem to form a cluster. An SUR estimation is thus justified.

Before turning to event effects, the second-lowest table panel presents the market models. Indeed, all airlines shares are sensitive to a market portfolio representing the economic climate of their home country. The short-term price changes in jet-grade kerosene increased the model fit for all except Finnair and SAS, but this control variable mostly does not exert statistically significant effects. Despite being close to zero in almost all cases, the kerosene returns exhibit negative signs which is possibly explained by hedging strategies of airline companies (Michel and Shaked, 1984) but cannot be pursued further here. Finally, the control variable for the 9/11 terrorist attacks underscores that airline shares were disproportionately affected even where the overall market downturns are already controlled for (Carter and Simkins, 2004). Taken together, the models seem to reasonably capture the normal return-generating process so that we can turn to the conflict on supranational competences in international aviation.

Let us start with the agenda-setting phase in the upper panel of Table 2 when the conflict involved the Commission and the Council only. Apparently, the markets received little economically relevant information from these early developments. We find only very few statistically meaningful deflections in individual return series. For example, investors of British Airways (BAW) and Continental Airlines (COA) valued the Council demand for an economic report on existing bilaterals negatively (event 2). Alitalia (AZA) investors profited when that report was published a few months later (event 8), while Lufthansa shareholders lost somewhat more than 4 per cent when the soft rights mandate was granted to the Commission (event 9).

Beyond these very limited and specific reactions, however, the last column suggests that the markets as a whole were relatively unimpressed by the conflict's initiation. During the agenda-setting phase we can reject the null hypothesis that all observed abnormal returns are in fact zero only for event 4 . It was a credible signal for investors that the whole College of Commissioners formally backed the supranationalization of external aviation relations. All other informal agenda-setting moves and threats of the Commission, however, as well as the number of consecutive Council meetings did not convey economically meaningful information. These results speak against the assumptions that investors follow either an intergovernmentalist or a functionalist reading of the integration process and rather suggest that they are sensitive to detailed formal steps if they are sensitive at all.

This institutionalist understanding is particularly emphasized if one looks at the "judicial action' phase in the following panel. Here we can observe much more pronounced market reactions. Markets considered the initiation of a formal European infringement procedure as a credible political signal when the Commission sent out reasoned opinions to the reluctant Member States in March 1998 (event 14). The Commission announcement to 


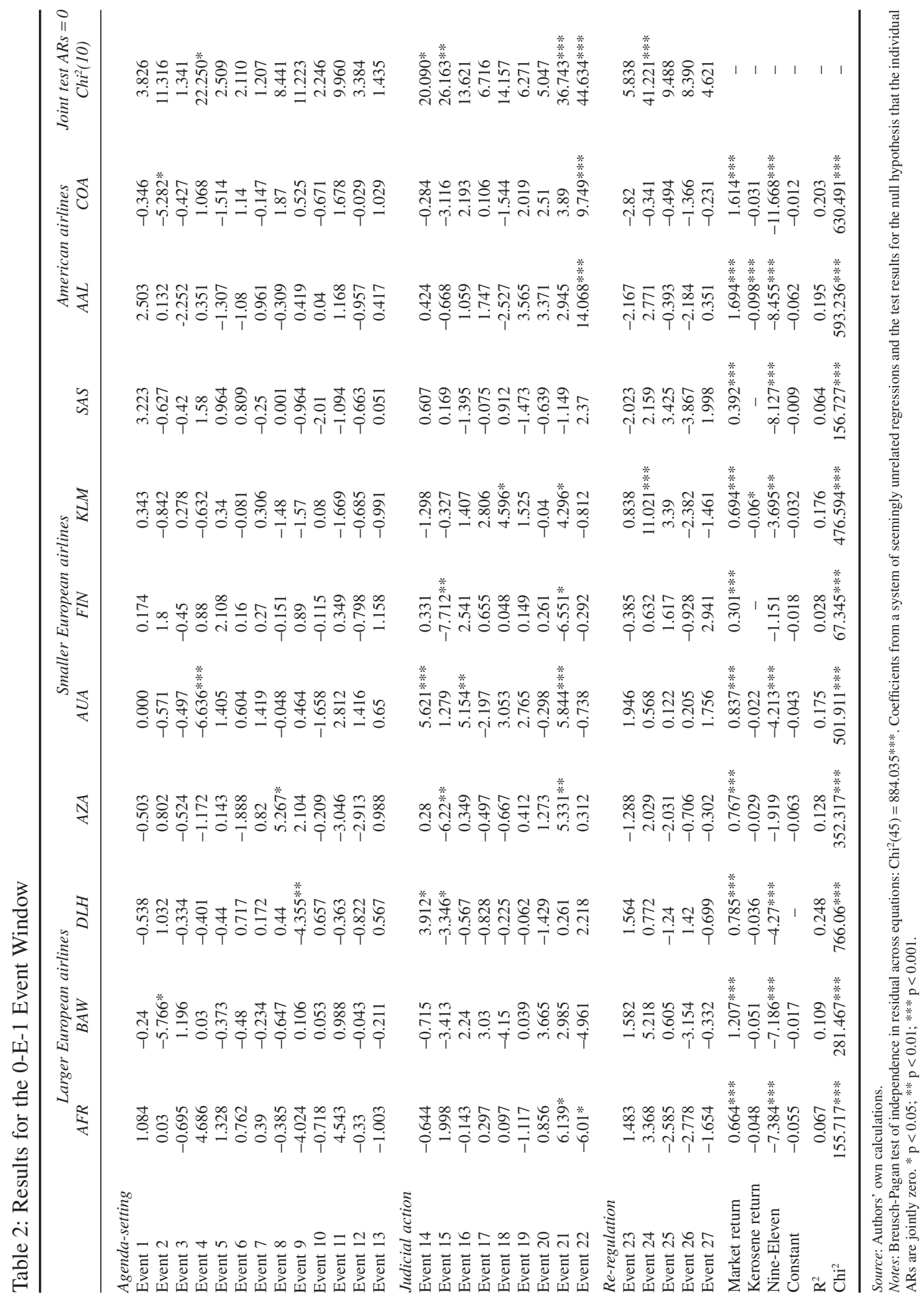


formally involve the ECJ seven months later likewise sent a credible signal for regime change in external aviation relations of the $\mathrm{EU}$ (event 15). The joint abnormal returns during the formal transmission of the files to the ECJ (event 16) and the recommendation of Advocate-General Tiziano (event 18) only barely fail to reach statistical significance. Yet, at this stage investors could not be sure yet whether the ECJ would actually take side with the Commission. But when Transport Commissioner De Palacio self-assuredly suggested that the ECJ would follow her demands just two weeks before the scheduled judgement (event 21), investors - especially those of European airlines - valued this as another strong signal for regime change. The reactions to the actual ECJ verdict in November 2002 (event 22), however, sent the most convincing message to markets that the regulatory context of their investment will be altered. Investors of American airlines in particular received new information they deemed to be relevant for their allocative decisions.

The final signal that led to aggregate and statistically meaningful investor reactions during the re-regulation phase was the formal surrender of the Council in June 2003 (event 24) that paved the way for a Commission mandate and a formal re-regulation of supranational competences in the external aviation relations of the EU. Afterwards, individual Commission moves (event 25) or the final signature under the newly established balance of powers (27) could not add any additionally relevant information for market participants.

In summary, the results strongly suggest that markets follow a rational-institutionalist reading of political conflicts over European integration. From all 27 publicly visible events during the conflict over external aviation relations, the judicial action phase and particularly those events that signalled an alliance of Commission and ECJ were perceived as the most convincing indications for an economically relevant change of the regulatory context. Investors seem to be aware of the nuanced strategies that the extant institutional framework provides for supranational actors wanting to overcome national resistance. In contrast, the unilateral actions of the Commission or the Member State governments were not as important economically as the functionalist or intergovernmentalist readings of integration process would suggest. The various agenda-setting efforts of the Commission and the Council meetings were of little relevance for financial markets. Such events only became credible once the ECJ was in the game.

Robustness checks support this reading (see web appendix). First, we allow for early information leakage by including one pre-event day. The formal Commission decision (event 7), the initiation of the judicial proceedings (15), the announcement of and the ECJ verdict itself (21 and 22), as well as the final Council surrender (24) are robust to this changed set-up. Only the submission of reasoned opinions (event 8) closely misses statistical significance, while two early signals from both the Council and the Commission are additionally picked up (events 7 and 10). Second, we allow for possibly delayed market responses by a window that includes five post-event days. This extended period contains more noise and thus has a lower power to detect event effects. But the confident anticipation of the ECJ judgment by the Commission (event 21) as well as the verdict itself (22) are again identified as economically relevant political signals in this setting.

The relevance of judicial integration strategies is also underlined if we look more closely at which political events affected market anticipations lastingly. To this end, we consider a hypothetical investor who held airline shares only during the political events. This cumulative perspective enables us to see which events created lasting abnormal returns that were not depleted by later political signals (Figure 1). We consider portfolios 
Figure 1: Cumulative Average Abnormal Returns over All 27 0-E-1 Event Windows

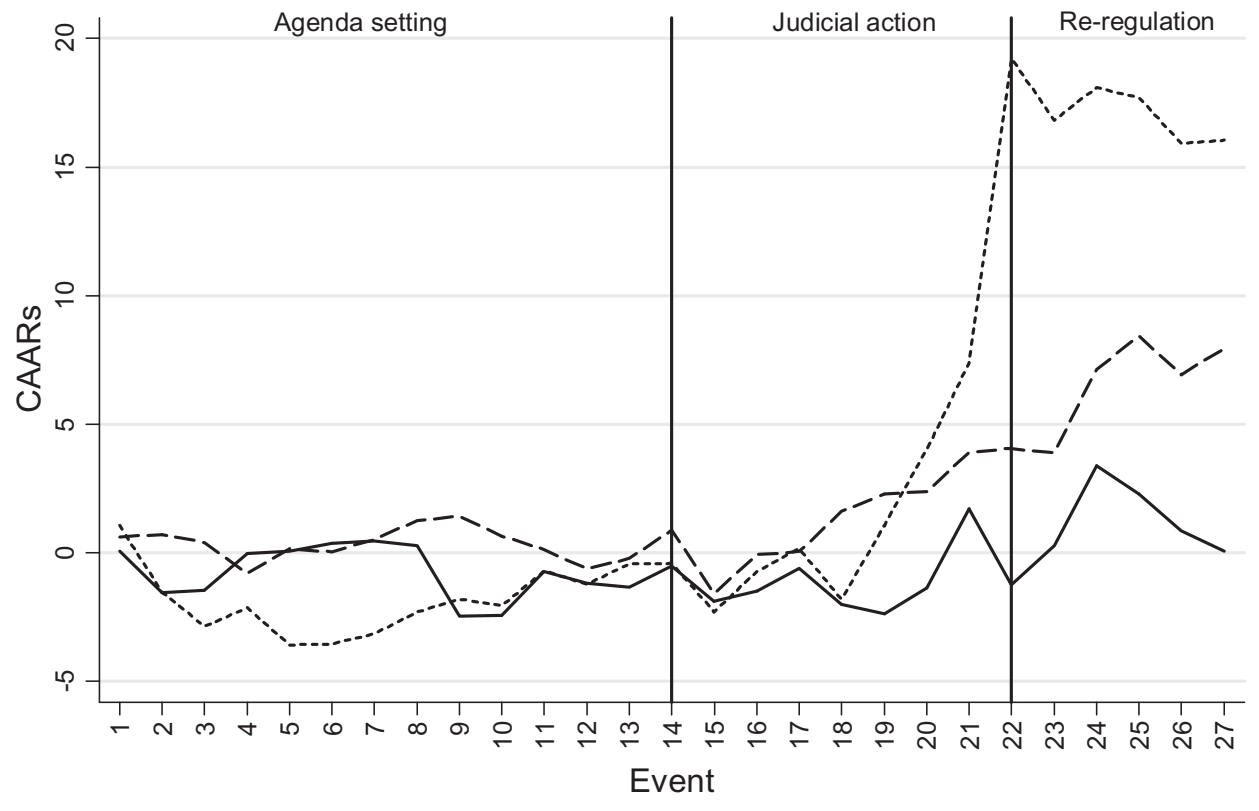

Large EU carriers - - - - Small EU carriers ……... US carriers

Source: Authors' own calculations.

of the large EU carriers (AFR, BAW, DLH), their smaller competitors (AZA, AUA, FIN, KLM, SAS) and the two American carriers (AAL, COA). Initially, this shows that abnormal returns on the shares of European carriers fluctuate around zero without lasting gains during the agenda-setting phase. The American portfolio lost slightly from early Commission and Council interaction (events 1 and 2), but the overall balance during the first conflict stage is also close to zero in the end.

The picture changes dramatically during the judicial action phase. Starting from the ECJ's advocate opinion (event 18), investors of small European and especially of American airlines would have generated substantial and lasting returns. This perspective highlights furthermore that the confident Commission announcement of the ECJ judgment and especially the verdict itself (events 21 and 22) were of particular importance for market participants and generated returns that did not have to be written off during later conflict stages.

Shifting to the re-regulation phase, all portfolios reacted positively to the final Council surrender (event 24), but these returns persisted only for investors of smaller European competitors. When the re-regulation of air service agreements settled the political conflict on nationality restrictions in the end (event 27), we find a clear picture on how financial markets valued the political outcome. Investors expected that the regime change was particularly positive for the profitability of investments in American airlines as evident in a cumulative gain of 16.04 percentage points above normal market variation. The smaller European airlines came out second; respective investments increased by 7.94 percentage 
points throughout all events that made up the conflict. The portfolio containing the three big European players, in contrast, would have ultimately produced no significant gains or losses during the overall set of political events (0.07 percentage points). Company-specific uncertainties during the final stages of regime change - for example, on British Airways' exclusive access to Heathrow, the looming merger between Air France and KLM, or Lufthansa's search for possible acquisitions - may explain this result. This reminds us that interpreting the distributive effects across airlines has to be taken with caution as the competitive environment of individual companies and thus their preference for Commission success varied over time (Dobson, 2010; Kassim and Stevens, 2010). However, independent from the actual direction of return effects, the analysis of cumulative portfolio returns once more underlines that the economically most relevant political signals came from the judicial strategies that enabled the Commission to overcome Member State resistance in co-operation with the ECJ.

\section{Conclusions}

Theorists of political integration are still at loggerheads with each other over the empirical relevance of intergovernmentalist, neofunctionalist or institutionalist explanations of competence transfers and decision-making in the EU. In this study, we have evaluated how financial markets assess the distribution of power between the European Commission and the Member States. Exploiting the fact that financial investors have substantial incentives to 'read' the economic relevance of political signals correctly, we uncovered the pattern of market reactions to the political conflict on nationality restrictions in the European airline industry. Our event study shows that investors considered ECJ support for the Commission plans as the most credible signal that regulatory changes were imminent and that the airlines' profitability would be affected by the attempts to reshape the international aviation regime. Early agenda-setting efforts of the Commission and intergovernmental signals, in contrast, provided hardly any systematic market reactions.

This pattern cannot be explained by the basic conjectures of neofunctionalist and intergovernmentalist theory alone, but it is in line with a rational-institutionalist reading of integration. Our analysis in particular supports Schmidt's (2000) argument that the Commission can break Member State resistance if it is able to attack the respective national competences with treaty infringement procedures. Market participants seem to understand that a renegotiation of the underlying treaty provisions is not very likely and that thus a successful alliance of the Commission and the ECJ heralds regime change in hitherto nationally regulated sectors. Our quantitative case study on these contemporaneous market reactions is thus also consistent with extant in-depth policy analyses that reconstruct the influence of the Commission-ECJ alliance along archival or interview-based research (Dobson, 2010; Kassim and Stevens, 2010, p. 169; Woll, 2006). More broadly, the repeatedly uncovered relevance of judicial proceedings aligns with calls for more research into the political preferences that drive decision-making in the ECJ.

On the most general level, the results presented here suggest that financial markets carefully consider the signals that the decision-making process in the EU emits. Investors follow the subtleties of day-to-day decision-making and mainly consider those signals to be economically relevant that alter the market of interest and thus the profitability of individual firms. Temporarily disaggregated analyses like the one presented here highlight 
more generally that political science can exploit the tools advanced in financial econometrics. In sectors with more easily predictable effects of regulatory choices - think of recent European regulations in the banking or in the tobacco sector - it will identify losers and winners of power transfers to Brussels more clearly. Financial markets shed light on the redistributive effects of policy decisions and thus enable us to evaluate the credibility of political signals for or against European integration.

Correspondence:

Christian Rauh

Social Science Research Centre Berlin (WZB)

Reichpietschufer 50

D-10785 Berlin

Germany

email: christian.rauh@wzb.eu

\section{References}

Association of European Airlines (AEA) (2004) Yearbook 2004 (Brussels: AEA).

Bechtel, M. and Schneider, G. (2010) 'Eliciting Substance from "Hot Air": Financial Market Responses to EU Summit Decisions on European Defense'. International Organization, Vol. 64, No. 2, pp. 199-223.

Binder, J. (1985a) 'Measuring the Effects of Regulation with Stock Price Data'. RAND Journal of Economics, Vol. 16, No. 2, pp. 167-83.

Binder, J. (1985b) 'On the Use of the Multivariate Regression Model in Event Studies'. Journal of Accounting Research, Vol. 23, No. 1, pp. 370-83.

Binder, J. (1998) 'The Event Study Methodology since 1969'. Review of Quantitative Finance and Accounting, Vol. 11, No. 2, pp. 111-37.

Brown, S.J. and Warner, J.B. (1980) 'Measuring Security Price Performance'. Journal of Financial Economics, Vol. 8, No. 3, pp. 205-58.

Carter, D. and Simkins, B. (2004) 'The Market's Reaction to Unexpected, Catastrophic Events: The Case of Airline Stock Returns and the September 11th Attacks'. Quarterly Review of Economics and Finance, Vol. 44, No. 4, pp. 539-58.

Chandra, R., Moriarty, S. and Willinger, G.L. (1990) 'A Re-examination of the Power Alternative Return-Generating Models and the Effect of Accounting for Cross-Sectional Dependencies in Event Studies'. Journal of Accounting Research, Vol. 28, pp. 398-408.

Chang, Y.-C. and Williams, G. (2001) 'Changing the Rules: Amending the Nationality Clauses in Air Services Agreements'. Journal of Air Transport Management, Vol. 7, No. 4, pp. 207-16.

Commission of the European Communities (2007) Flying Together: EU Air Transport Policy (Luxembourg: Office for Official Publications of the European Communities).

Delreux, T. (2011) 'The Relation between the European Commission and the EU Member States in the Transatlantic Open Skies Negotiations: An Analysis of Their Opportunities and Constraints'. Journal of Transatlantic Studies, Vol. 9, No. 2, pp. 113-35.

Dobson, A. (2010) 'Civil Aviation and European Integration: Creating the Seemingly Impossible SEAM'. JCMS, Vol. 48, No. 4, pp. 1127-47.

Doganis, R. (2001) The Airline Business in the 21st Century (London: Routledge).

Doganis, R. (2002) Flying Off Course: The Economics of International Airlines (London: Routledge).

Fama, E., Fisher, L., Jensen, M. and Roll, R. (1969) 'The Adjustment of Stock Prices to New Information'. International Economic Review, Vol. 10, No. 1, pp. 1-21. 
Franchino, F. (2007) The Powers of the Union: Delegation in the EU (Cambridge: Cambridge University Press).

Füss, R. and Bechtel, M. (2008) 'Partisan Politics and Stock Market Performance: The Effect of Expected Government Partisanship on Stock Returns in the 2002 German Federal Election'. Public Choice, Vol. 135, No. 3, pp. 131-50.

Havel, B. (1997) In Search of Open Skies: Law and Policy for a New Era in International Aviation (The Hague: Kluwer Law International).

Howells, P. and Bain, K. (2001) The Economics of Money, Banking and Finance: A European Text (3rd edition) (Harlow: Prentice Hall).

Kassim, H. (1996) 'Air transport'. In Kassim, H. and Menon, A. (eds) The European Union and National Industrial Policy (London: Routledge).

Kassim, H. and Stevens, H. (2010) Air Transport and the European Union: Europeanization and Its Limits (Basingstoke: Palgrave Macmillan).

Lamdin, D. (2001) 'Implementing and Interpreting Event Studies of Regulatory Changes'. Journal of Economics and Business, Vol. 53, No. 2-3, pp. 171-83.

MacKinlay, C. (1997) 'Event Studies in Economics and Finance'. Journal of Economic Literature, Vol. 35, No. 1, pp. 13-39.

Michel, A. and Shaked, I. (1984) 'Airline Performance under Deregulation: The Shareholders Perspective'. Financial Management, Vol. 13, No. 2, pp. 5-14.

Moravcsik, A. (1993) 'Preferences and Power in the European Community: A Liberal Intergovernmentalist Approach'. JCMS, Vol. 31, No. 4, pp. 473-524.

Morrell, P. (1998) 'Air Transport Liberalization in Europe: The Progress So Far'. Journal of Air Transportation World Wide, Vol. 3, No. 1, pp. 42-61.

O'Reilly, D. and Stone-Sweet, A. (1998) 'The Liberalization and Reregulation of Air Transport'. Journal of European Public Policy, Vol. 5, No. 3, pp. 447-66.

Pollack, M. (1997) 'Delegation, Agency and Agenda Setting in the European Community'. International Organization, Vol. 51, No. 1, pp. 99-134.

Scharpf, F.W. (2010) 'The Asymmetry of European Integration, or Why the EU cannot be a "Social Market Economy". Socio-economic Review, Vol. 8, No. 2, pp. 211-50.

Schmidt, S.K. (2000) 'Only an Agenda Setter? The European Commission's Power over the Council of Ministers'. European Union Politics, Vol. 1, No. 1, pp. 37-61.

Schneider, G. and Tröger, V.E. (2006) 'War and the World Economy: Stock Market Reactions to International Conflicts'. Journal of Conflict Resolution, Vol. 50, No. 5, pp. 623-45.

Sorensen, F., Van Weert, W. and Lu, C.-J. (2003) 'ECJ Ruling on Open Skies Agreements v. Future International Air Transport'. Air and Space Law, Vol. 28, No. 1, pp. 3-18.

Staniland, M. (1996) 'Open Skies - Fewer Planes? Public Policy and Corporate Strategy in EU-US Aviation Relations'. European Policy Paper 96(3) (Pittsburgh, PA: University of Pittsburgh).

Staniland, M. (1999) 'Transatlantic Air Transport: Routes to Liberalization'. European Policy Paper 99(6) (Pittsburgh, PA: University of Pittsburgh).

Tsebelis, G. and Garrett, G. (2001) 'The Institutional Foundations of Intergovernmentalism and Supranationalism in the European Union'. International Organization, Vol. 55, No. 2, pp. 357-90.

Woll, C. (2006) 'The Road to External Representation: The European Commission's Activism in International Air Transport'. Journal of European Public Policy, Vol. 13, No. 1, pp. 52-69.

Zellner, A. (1962) 'An Efficient Method of Estimating Seemingly Unrelated Regressions and Tests for Aggregation Bias'. Journal of the American Statistical Association, Vol. 57, No. 298, pp. 348-68. 